\title{
REGIONAL SYSTEM OF MUNICIPAL WASTE IN LATVIA AND NEW ENVIRONMENTAL ENGINEERING CHALLENGES FOR THE PERIOD TILL YEAR 2020
}

\author{
Indulis Emsis \\ Latvia
}

After Latvia regained its independence in 1991, national municipal waste management (MWM) policy and legal framework with integrated EU environmental and sector policy was created from scratch. Regional, inter-municipal waste management infrastructure is created and a respective institutional system is constantly being improved. 10 waste management regions (Picture 1) have been created in Latvia, and by motivating municipalities to combine their efforts, a cheaper and more efficient (scale economies), solidary (all households of the same region pay equal municipal waste burial rates and same service charge in the business area of a particular operator) and more environmentally friendly operation of MWM system was achieved.

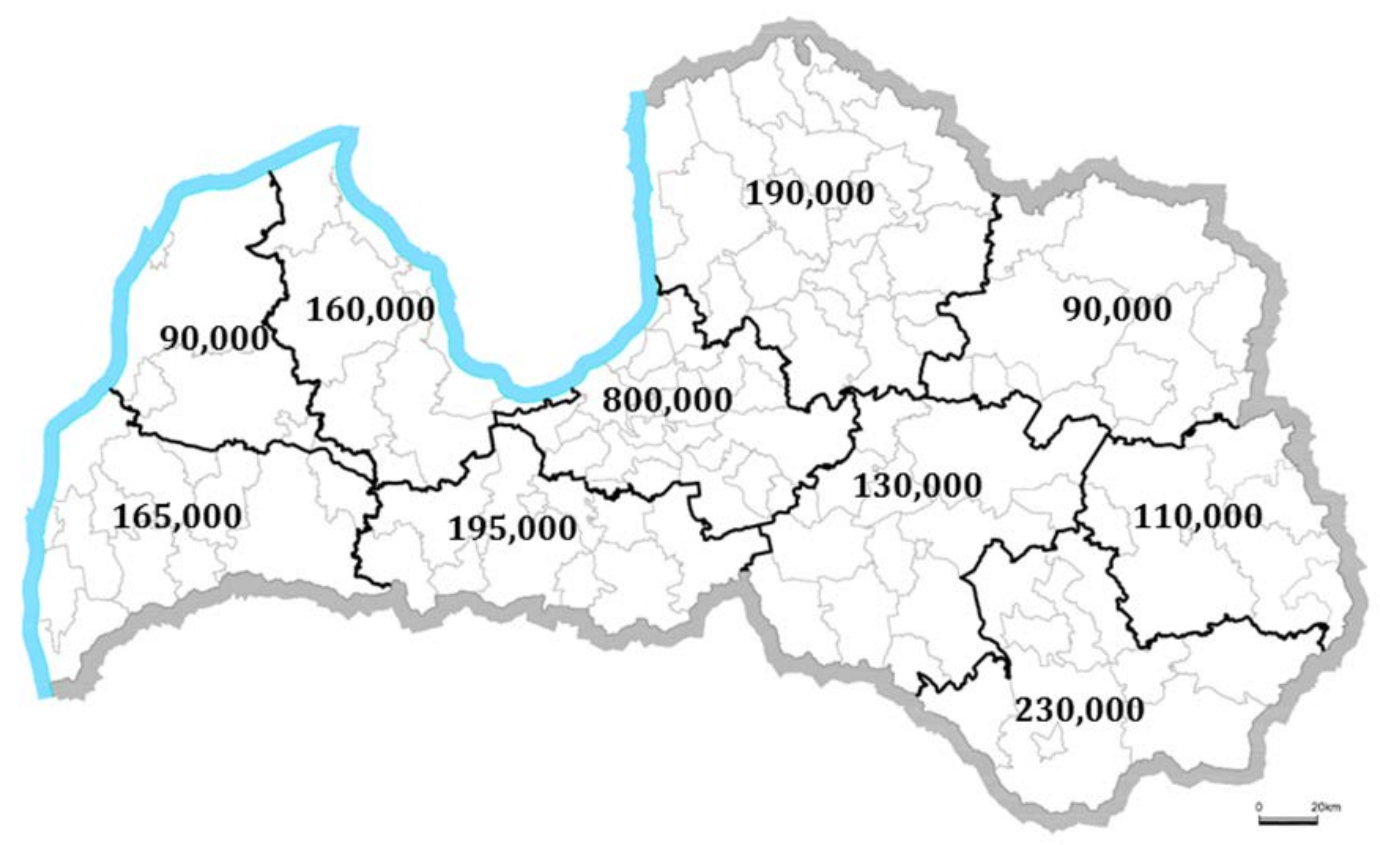

https://doi.org/10.15626/Eco-Tech.2014.029 
Picture 1. "Regional principle: 10 waste management regions in Latvia (number of residents)"

The infrastructure in MWM regions may be arranged both by polycentric (several MWM centres belonging to various economic operators) or monocentric (one MWM centre) approach, however, with one exception, in all MWM regions there is one sanitary waste burial landfill, hereafter - Landfill (Pic.2).

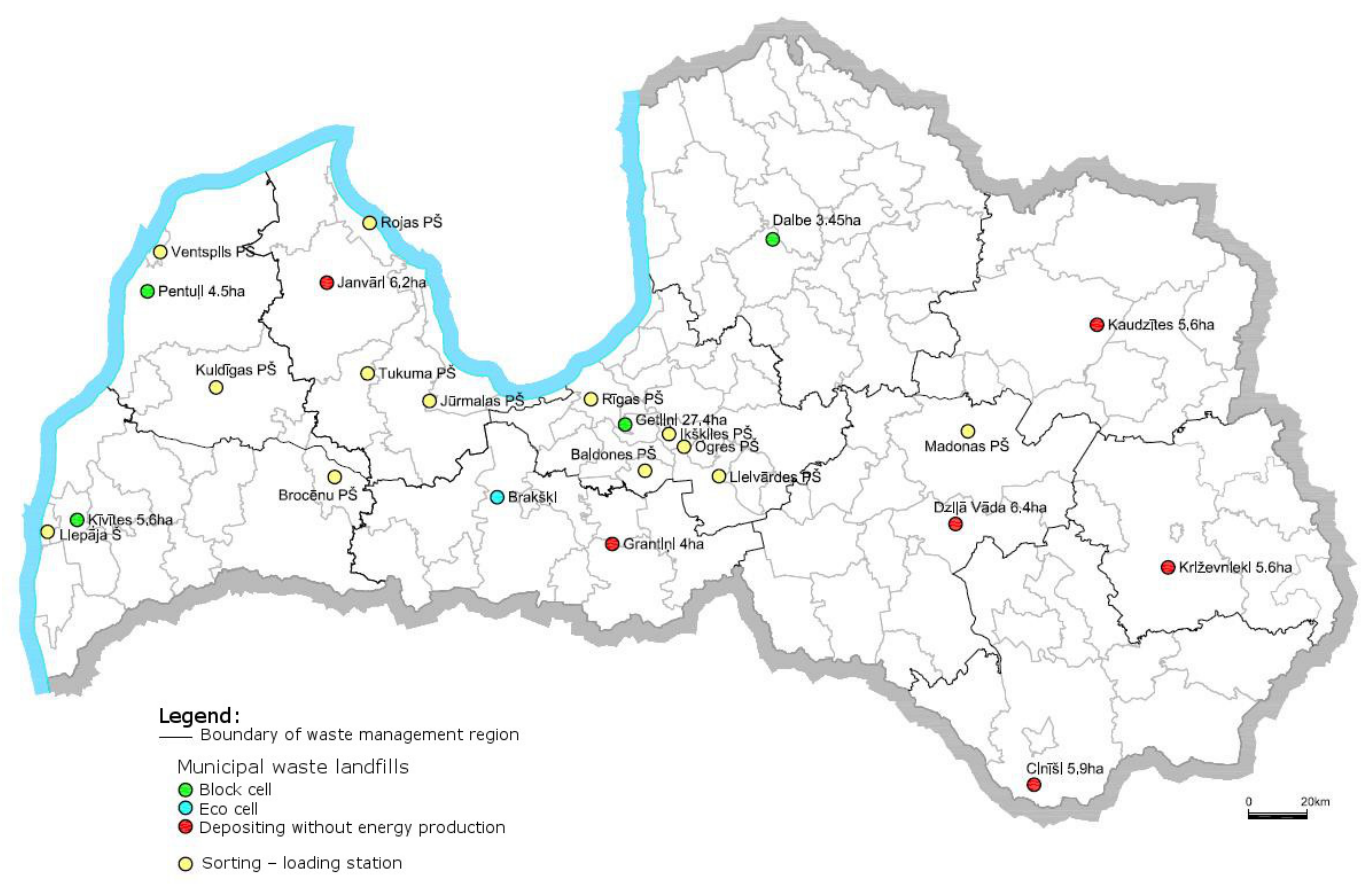

Picture 2. "Inter-municipal operators manage 11 landfills - in future WM centres.”

From 1993 till 2013 the public sector has invested 150 million EUR in MWM infrastructure, achieving that:

1) all waste disposal sites from the Soviet times are closed, waste flow is controlled and managed;

2) all waste, which does not get to recycling or regeneration facilities, is buried in environmentally friendly way in a landfill of the respective MWM region;

3) regional MWM system is cheap for households, payment for WM does not exceed $0.7 \%$ from total costs of households;

4) burial rate is gradually increasing with every year (at the moment it varies between 14 - 32 EUR/t in different landfills), by increasing natural resource tax for waste buried in landfills the recycling and regeneration thereof is stimulated;

5) in five landfills gas from waste is used in cogeneration facilities, electricity and heat is produced; three facilities have started operation in order to produce fuel from waste (RDF), which has a reducing impact on climate change and contributes to Latvia's energy independence; 
6) increase in the capacity of waste separation, recycling and regeneration allows decreasing the amount of buried waste and creates new national business, where waste becomes raw material and start a new turnover cycle.

In order to describe different engineering solutions for environment protection and achieving of MWM goals in different regions, four cases will be analysed.

\section{MWM REGION OF GREATER RIGA}

In the Greater Riga region waste that is already sorted in households and companies for recycling, is delivered to a sorting station where they are repeatedly sorted and further delivered to recycling or regeneration companies. However, the biggest amount of waste (300,000 t/a) ends up in the biodegradation cells of Baltic's biggest waste burial landfill Getlini (Pic.3). Waste gas is collected, purified and used in 6 MW load power unit for the production of electric power (34,000 MWh/a) and heat (26,000 MWh/a). Heat is used for the heating of greenhouses (total area $1.1 \mathrm{ha}$ ) where tomatoes with an average productivity of $50 \mathrm{~kg} / \mathrm{m}^{2}$ are grown (Pic.4).

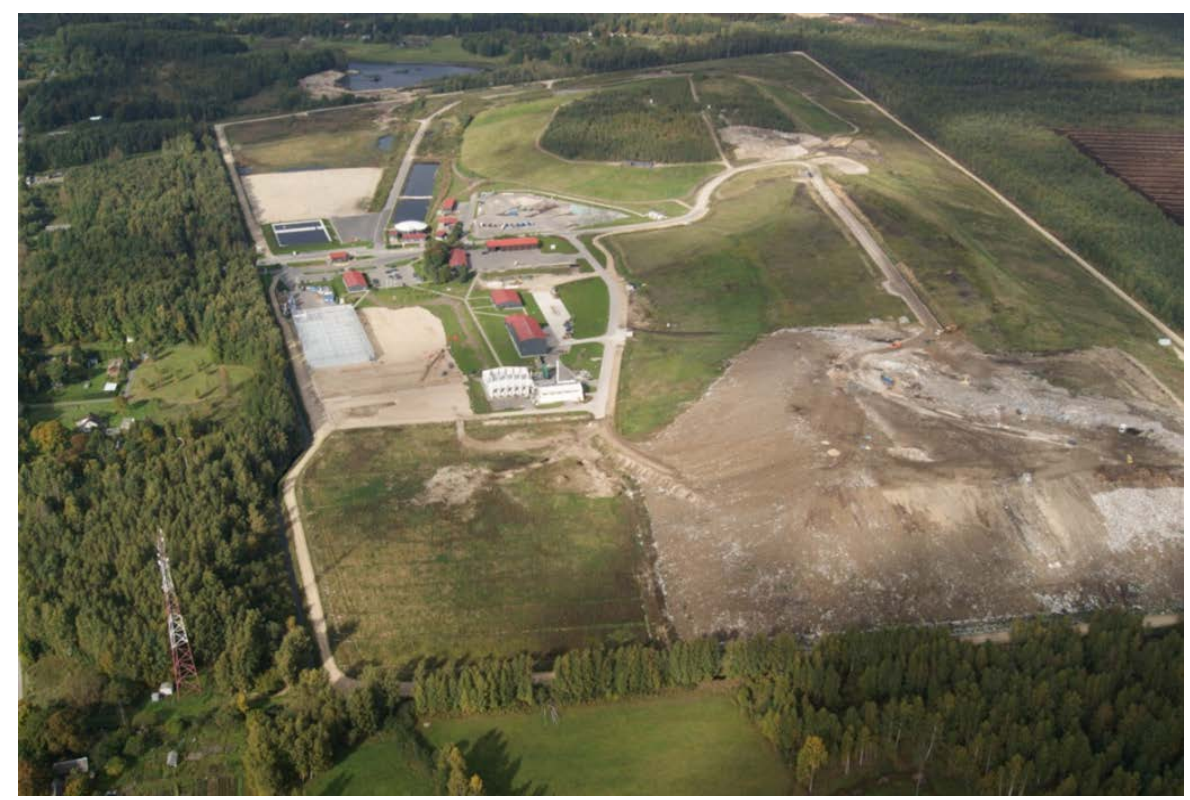

Picture 3. "Waste management landfill "Getlinil” of the Greater Riga area”

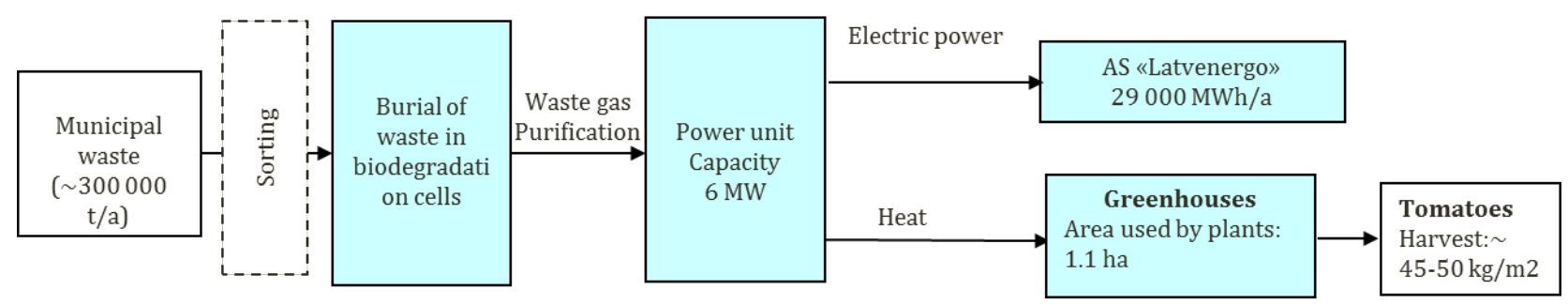

Picture 4. "Flowchart of SIA "Getlini EKO”" 
At the moment design works of previously unsorted municipal waste sorting factory are started in the free territory of Getlini landfill. The factory will automatically sort waste intended for recycling or regeneration, thus reducing the remaining amount of admixtures in organic waste by $60 \%$. Further at least two scenarios are possible:

1. Organic waste fraction gets into anaerobic fermentation biocell where organic substance deterioration is facilitated and accelerated, so that within $7-10$ years methane generation would be completed. Biocell is opened, excavated material is repeatedly sorted and the residual organic material is delivered to composting facilities for production of compost and for starting a new cycle of its utilization.

2. Organic waste fraction gets into closed, special anaerobic fermentation methane gas production facilities, and in the next cycle the organic material is composted and returned to nature to be further used as a fertilizer.

Which one of the future scenarios will be more viable depends on development of EU legal framework; successful, cost-effective engineering solutions and pilot projects. Supposedly Linnaeus Eco-Tech will also give the necessary impulses as regards innovations in technological solutions.

\section{VENTSPILS MWM REGION}

In Ventspils region unsorted municipal waste (25,000 t/a) ends up in municipal waste sorting and recycling facility where after initial sorting, waste is divided into two main fractions: wet organic (30\%) and dry (70\%) for further processing in sorting fractions. Wet and dry fractions are separated using high pressure pressing (280 bar) technology.

Wet fraction containing organic substances is further transported to anaerobic fermenter for production of biogas. The residual waste after fermentation - digestate is separated from excess water and gets into compost field.

Dry fraction is sorted in order to obtain recyclable materials (for example, metals and glass) and waste suitable for the production of heating fuel (Pic.5).

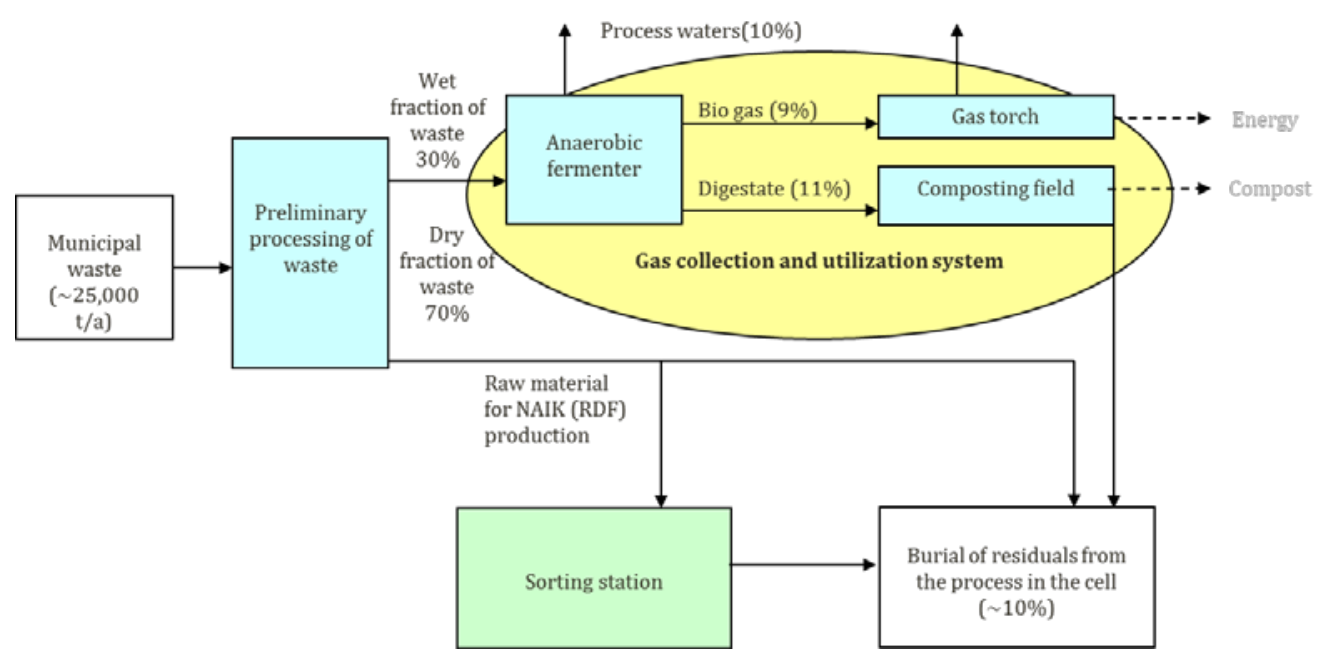

Picture 5. "Flowchart of Ventspils MWM region" 
Benefit of the method - organic material, material selected for recycling and regeneration (total 90\%) does not go to landfill (pic. 6). However, it must be added that costs of purchase, installation and maintenance of technological facilities are rather high (26 EUR/t.)

Future prospects of technological solution will significantly impact the development of the RDF market in the region (demand and competition) and regulations regarding imported fuel.
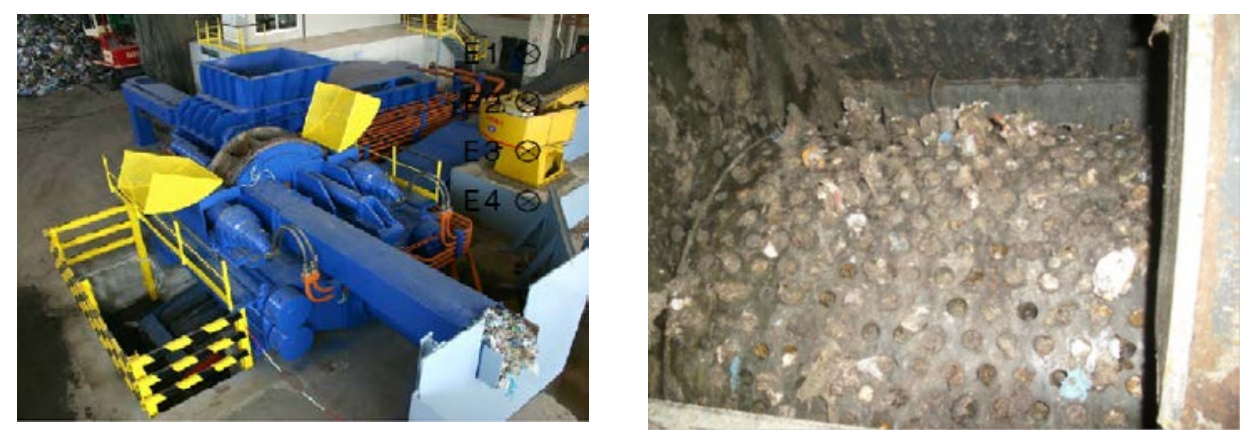

Picture 6. „Waste sorting and recycling facility in Ventspils MWM region”

\section{ZEMGALE MWM REGION}

Sorted household waste from Zemgale region goes to 313 separated collection points for further recycling. Unsorted collected municipal waste (30,000 t/a) goes to sorting station (Pic.7) where sorting facilities separate repeatedly recyclable fraction (15\%); biologically degradable fraction ( $50 \%)$; heating fraction obtained from waste (10 \%?) and fraction for burial in waste landfill ( 25\%).



Picture 7. "Flowchart of Zemgale MWM region" 
Organic waste goes to specially equipped biocell - a biodegradation field where under controlled circumstances in anaerobic fermentation process organic material deterioration process takes place (Picture 8).

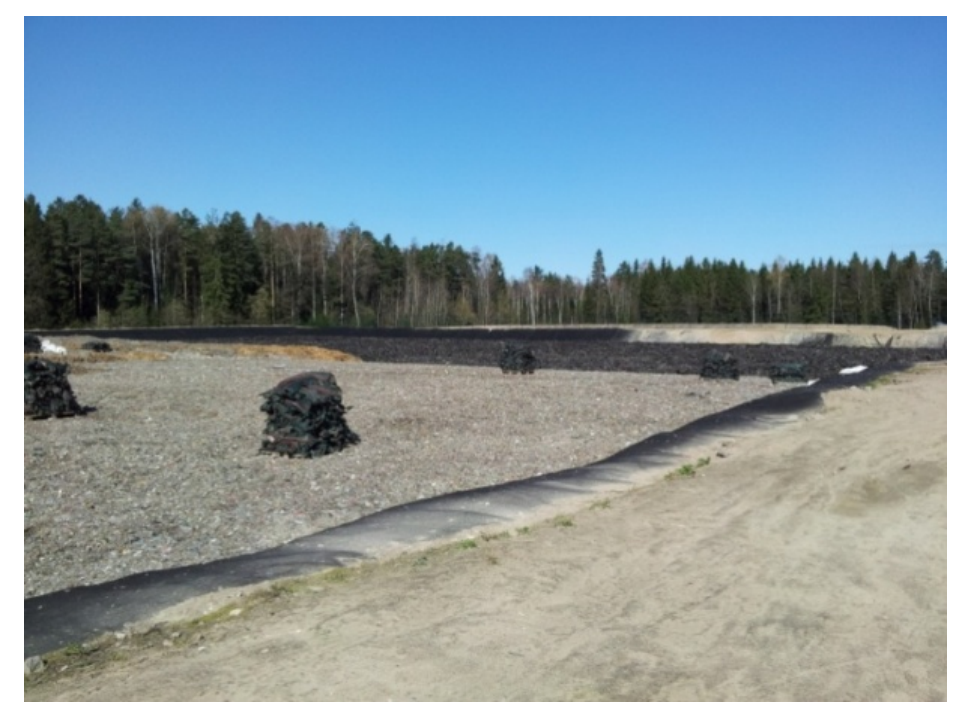

Picture 8. "Biodegradation field in Zemgale MWM region”

As a result of the process gas from waste that has been created is collected and delivered to cogeneration facilities for production of electric power and heat $(1,000$ MWhel.). It is estimated that after 15 years the biocell will be opened and substrate will be repeatedly sorted, which will result in technical compost, utilizable fraction and residual material to be buried in a disposal site (Pic.9).

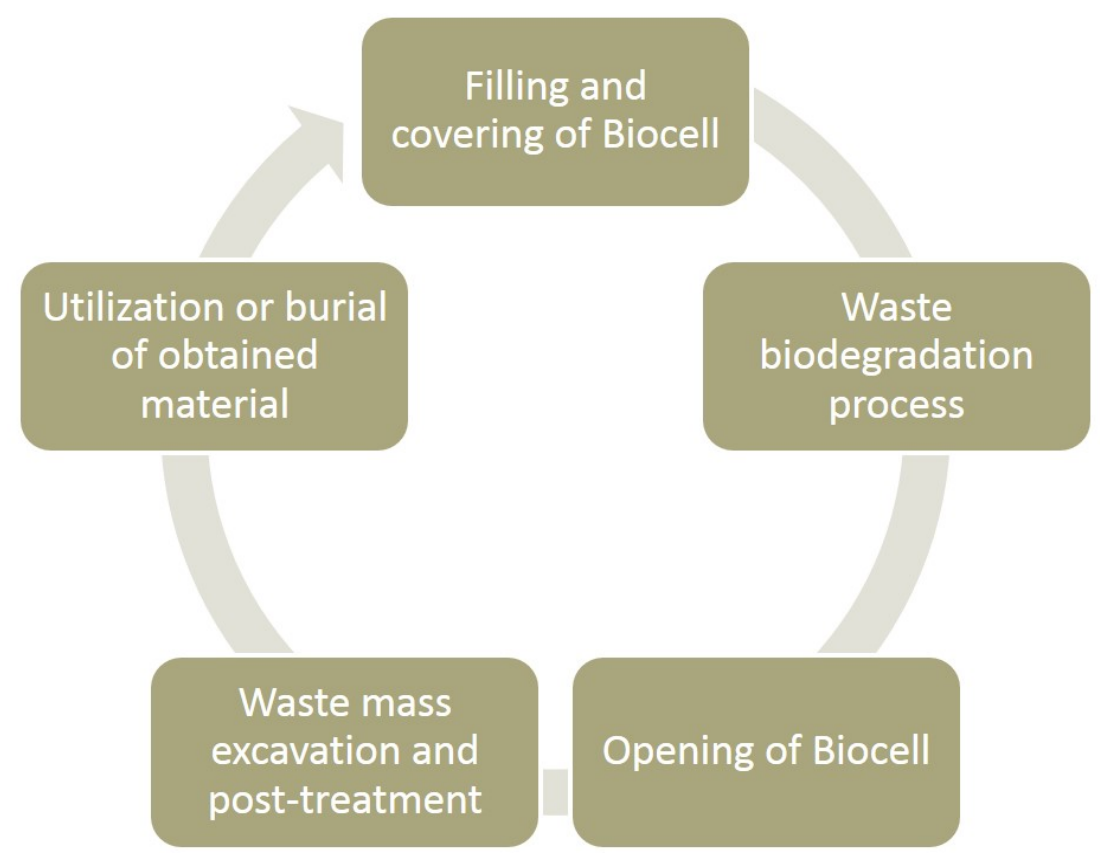

Picture 9. "Technological cycle of biodegradation cell” 
Future perspective of technological solution will depend on EU and national legal framework, i.e., whether processing of organic fraction in biocell and postponing of final processing for 15 years will be permitted. Similar as with the case of Ventspils, RDF market conditions will also be important.

\section{NORTHERN VIDZEME (ZIEMEḶVIDZEME) MWM REGION}

Unlike in other cases from the regions, in Northern Vidzeme main focus is on education of waste producers and sorting of waste in places of its origin. Residents and legal entities are sorting waste and delivering it to specially equipped 223 EKO points; 14 fields (Pic.10) and special containers for collection of packaging, and separately for PET collection in centres of populated areas in easily accessible places. For the collection of separated recyclable waste EKO bags and EKO boxes are also used. In this way it was possible to separate $\sim 20 \%$ from total municipal waste volume (50,000 m3) for recycling. Residual amount of unsorted municipal waste, which is not used for recycling and regeneration, is delivered after pre-treatment to energy cell (16,000 t/a) of landfill Daibe. Waste gas is collected and used for power production (1000 MWh el). Separated biological waste is brought to composting field. Compost is used in landfill to cover stored waste.

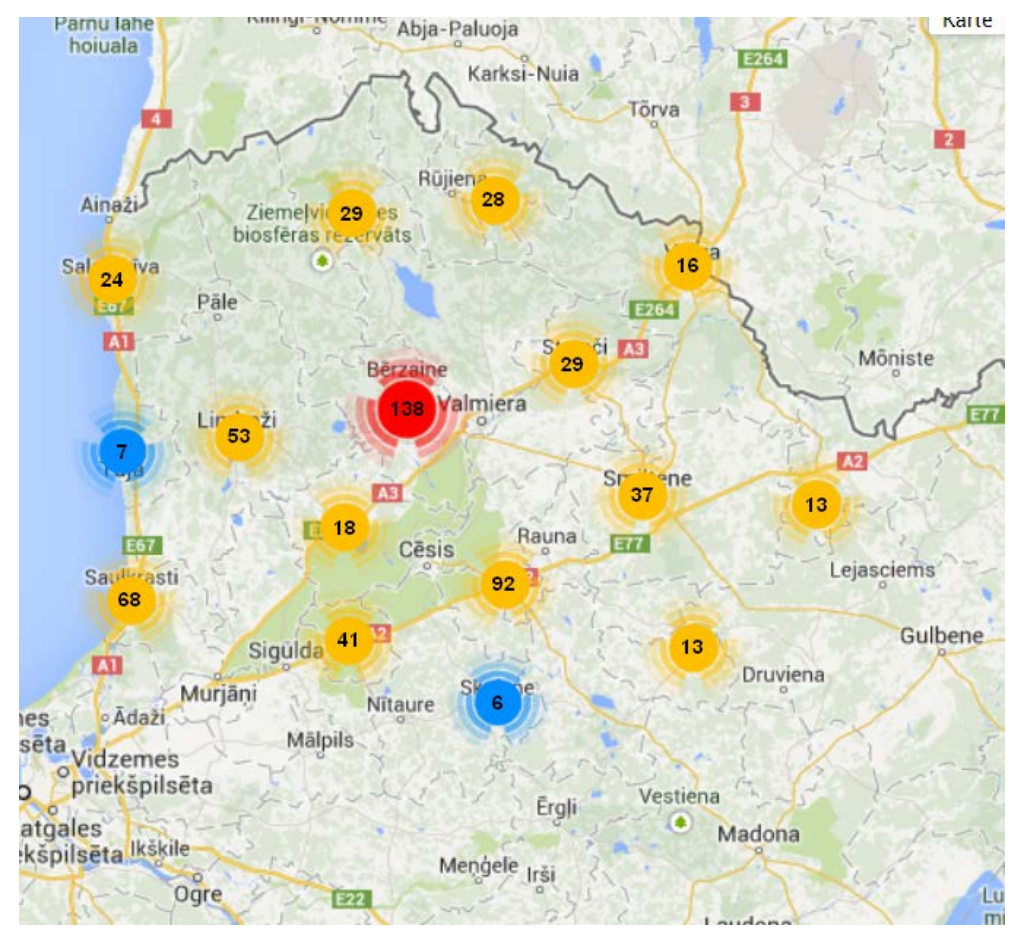

Picture 10. "Separated waste collection system in Northern Latvia MWM region"

The following conclusions can be drawn from the analysed municipal waste management cases in MWM regions:

1) MWM regional principle, where the state coordinates the combined efforts of many municipalities in implementing a waste management policy which is widely 
accepted by the society and is environmentally friendly, which is affordable to everyone and solidary in terms of the area, has completely paid off. Based on a legally established partnership 119 municipalities of Latvia are merged in 10 MWM regions.

2) In each region (with one exception) a single modern, environmentally friendly deposition landfill has been created which is managed by an economic operator established by municipalities of the region. Many municipalities have organized public procurement tenders to choose waste collection and management operators for their territory or a single part thereof (polycentric principle). Others, unlike previously mentioned, by mutually combining efforts have entrusted these services to their own inter-municipality companies ("in-house"), which then manage also a deposition landfill and municipal MWM infrastructure in the region (monocentric principle). Both models have proved their viability and the freedom of municipalities in choosing either of the models should not be restricted.

3) Different solutions in regions for reaching common goals defined in the National Waste Management Plan allow municipalities learning from each other, analysing best practice and strengths of the solution, as well as identifying the mistakes and disadvantages in order to find new ideas for technological and administrative operational solutions and to provide high quality MWM services to residents.

MWM new challenges for the period $2014-2020$

Change in the way of thinking switching from waste to raw materials, from undesired waste to desired raw materials. New aspirations in MWM policy are:

- $\quad$ Change of habits - convincing residents; improving system of motivating incentives (price control, bonuses) and sanctions (fines).

- $\quad$ To develop and improve separated waste collection system, till the end of period to prepare for secondary utilization and recycling at least $50 \%$ of weight and another $20 \%$ for other material regeneration from total amount valid for recycling.

- $\quad$ To reduce the amount of buried biologically degradable waste to 35\% compared to amount buried in landfills in 1995.

- $\quad$ To develop further waste preparation of presently non suitable fractions for recycling and regeneration (RDF; biogas; bio-methane, etc.). In this field new, more efficient technological solutions of anaerobic fermentation and bio-methane production and utilization are expected.

- Especially significant will be cost-efficient technological solutions of the treatment and utilization of the post-fermentation substrate. 